\title{
Practicum Workshop and Learning Media Quality in the Light Vehicle Engineering Department of Vocational High Schools
}

\author{
Arief Kurniawan*, Tri Kuat, Purnawan \\ Universitas Ahmad Dahlan, Jl. Pramuka No. 42, Pandeyan, Umbulharjo, Yogyakarta, Indonesia \\ *Corresponding author, e-mail: arief.kurniawan@pvto.uad.ac.id
}

\begin{abstract}
The study is to determine the quality of workshop practice and media learning of light vehicle engineering in Vocational High Schools in terms of (1) the facilities and infrastructure of laboratory and (2) the use of instructional media practices of light vehicle engineering. The collection of data used the method of observation, documentation, interview. This type of qualitative research is a case study approach, involving five internship supervisor teachers and workshop managers. The results of the study showed that the practice of Automotive Engine Repair with spacious $84 \mathrm{~m}^{2}$, Automotive Chassis Repair with a spacious $72 \mathrm{~m}^{2}$, Automotive Electrical Repair with spacious $24 \mathrm{~m}^{2}$ had not yet met the standard minimum as suggested at the Minister of Education and Culture Regulation number 34 of 2018. The use of practical learning media was less effective because: (1) the comparison of study groups with the area of the workshop was not balanced, (2) the existence of some practicum subjects scheduled in the same day resulted in the students were practicing simultaneously at one time, and (3) the lack of practicum facilities.
\end{abstract}

Keywords: light vehicle engineering, practicum learning media, workshop quality

How to Cite: Kurniawan, A., Kuat, T., \& Purnawan. (2020). Practicum workshop and learning media quality in the light vehicle engineering department of vocational high schools. Journal of Vocational Education Studies, 3(1), 39-50. DOI: https://doi.org/10.12928/joves.v3i1.2143.

\section{INTRODUCTION}

Vocational high school is an institution of education that prepares its students to be ready to work. This objective is in line with the Indonesian Law number 20 of 2003 that the vocational high school prepares prospective skilled workers and excel in their fields (MONE, 2003). Brown (1979) stated that the vocational education is dynamic and constantly changing to follow the development of the industrial world, and standards are set so that the market will accept the ability and knowledge of the students. According to Sudira (2012), vocational education is education that prepares formation of skills, knowledge, behavior, attitudes, habits of work, and the appreciation of the jobs that are needed by the public world of business/industry, supervised by the public and the government or in the contract with institutions as well as product-based. Vocational education gave supplies to the students with skills that can be used as supplies for work, for the purpose primary of school secondary vocational is to prepare the participant students are immediately to be able to work. To achieve the things that the school secondary vocational should provide learning that is feasible to provide facilities that adequate in order to obtain results in accordance with expectations, i.e., graduate Vocational High Schools with competence ready to work. Amenities are realized by giving workshops with media learning that adequate.

A laboratory or workshop is a place to conduct the learning practices of students in learning a skill. Thier (1970: 7) explains that the workshop practice of labor is a place that used to carry out the formation of skills and conduct experiments in science. Sukardi (2008: 30) mentioned that practical workshops are one of the means of technical and vocational education that serves as a place to practice and develop one's psychomotor skills that will explore a skill. Prosser (cited in Dharma, 2013: 16) states that the education of vocational 
be efficient if the environment where learning students is a replica of the place of work that actually.

The function of the laboratory or workshop in the Vocational High Schools can provide convenience for teacher educators to transfer the science knowledge and skills to be easily understood by the participant students to integrate between educational theory in class and practice in the workshop. The function of the workshop as a place of practice in schools was also revealed by Rochadi (2011), that a workshop in a school is a place to transfer competencies. Transfer the competence of the students as inputs in gave the training with all the facilities that exist to acquire competencies that are expected, the training that is in the school as a process, then output it is the competence of knowledge of students who are expected to conform to the field of science that is in demand. Such as that disclosed Aurigemma et al. (2013: 138) "if we can better understand how knowledge and skills are deployed in real-world engineering problem solving, we can better identify design principles to assist us in developing educational models that Achieve fidelity between the two sites of the classroom and the workplace whether it be a lab or industry. " The combination of the two places between classes and space practices will provide convenience to provide an understanding of the material to the participant students in accordance with the competencies that will be controlled. It is supported by the research, which states that there is influence positively and significantly on the feasibility of workshops and the achievement of learning it together on preparedness work (Sukardi, 2016).

Role important workshop in the Vocational High Schools as a place to practice control of competence, the facilities, and media learning should be managed by both to provide facilities to the participants of students that can be practiced to achieve the skill competencies that are expected. Such as that disclosed by Salindeho (2010: 522) that the lab is the tip of the spear of an institution of education. Based on the purpose of the Vocational High Schools, which prepares personnel work which prepared the work, the Vocational High Schools required to follow the needs of the market industry that is constantly evolving. To meet these objectives, the government provides a minimum standard of practice facilities in the Minister of Education and Culture Regulation No. 34 of 2018 regarding the types, ratios, and descriptions of practice space infrastructure standards on expertise competencies (MOEC, 2018). In this study, the Light Vehicle Engineering major. But every Vocational High School in Indonesia does not fully have the capability that is equal to prepare facilities supporting practices that adequate. Because the researchers are interested in researching the workshop work practice at Muhammadiyah 1 Playen Vocational High School at the Department of Engineering, Light Vehicle Engineering to know about the feasibility of workshop practice in schools is to prepare the personnel skilled and ready to work by the areas of competence.

This study aims to provide an overview of the quality of the practice workshop of the Department of Light Vehicle Engineering at Vocational High School. The quality of the workshop is in terms of (1) facilities and infrastructure support the learning lab at the Department of engineering Light Vehicle Engineering, (2) the use of a medium of learning that are in the garage working practices majors light vehicle engineering. Research this can be used as material evaluation themselves against Muhammadiyah 1 Playen Vocational High School, mainly majoring in Mechanical Light Vehicle Engineering, to develop back in facilities that have been there to meet the deficiencies that exist for this.

\section{RESEARCH METHODS}

This study is to provide an overview of the quality of practical workshops in the Department of Light Vehicle Engineering in Vocational High Schools. This research is an exploratory type case study (Nurdin \& Hartati, 2019:37) used to analyze the quality of practical workshops in the Department of Light Vehicle Engineering at Muhammadiyah 1 Playen Vocational High 
School. The research subjects in the study were subject matter teachers who used practical workshop facilities, head of the workshop majoring in Light Vehicle Engineering, and Laboratory or Toolman.

The quality of practical workshops in this study describes: (1) facilities and supporting facilities for practicum learning in light vehicle engineering majors, (2) utilization of learning media contained in practical workshops in light vehicle engineering majors. Data obtained using the method of documentation, observation, and interviews. Analysis of the data in this study using descriptive qualitative methods. The data collected is justified by the triangulation of sources and then confirmed by relevant investigations.

\section{RESULTS AND DISCUSSION}

The first discussion is about supporting facilities for light vehicle engineering workshop practice. The results of the documentation of the Light Vehicle Engineering practice workshop facilities consist of 3 workshops, namely:

Table 1. The extent of the Workshop for Light Vehicle Engineering Practices

\begin{tabular}{|c|c|c|c|}
\hline No & Lab/workshop & \multicolumn{2}{|c|}{ Workshop area } \\
\hline 1 & Automotive Engine Workshop & $7 \mathrm{~m} \times 12 \mathrm{~m}=$ & $84 \mathrm{~m}^{2}$ \\
\hline 2 & Automotive Chassis Workshop & $9 \mathrm{~m} \times 8 \mathrm{~m}=$ & $72 \mathrm{~m}^{2}$ \\
\hline 3 & Automotive Electrical Workshop & $3 \mathrm{~m} \times 8 \mathrm{~m}=$ & $24 \mathrm{~m}^{2}$ \\
\hline
\end{tabular}

In the list, the light vehicle engineering practice workshop at Muhammadiyah 1 Playen Vocational High School is divided into three practice workshop areas. The first practice area is the Automotive Engine Workshop has an area of $84 \mathrm{~m} 2$ divided into two areas, a space to store the practice equipment engine stand and an area to carry out practical activities. When learning is complete, the area used to practice is used for parking the practice vehicle. The following is an automotive engine practice workshop.
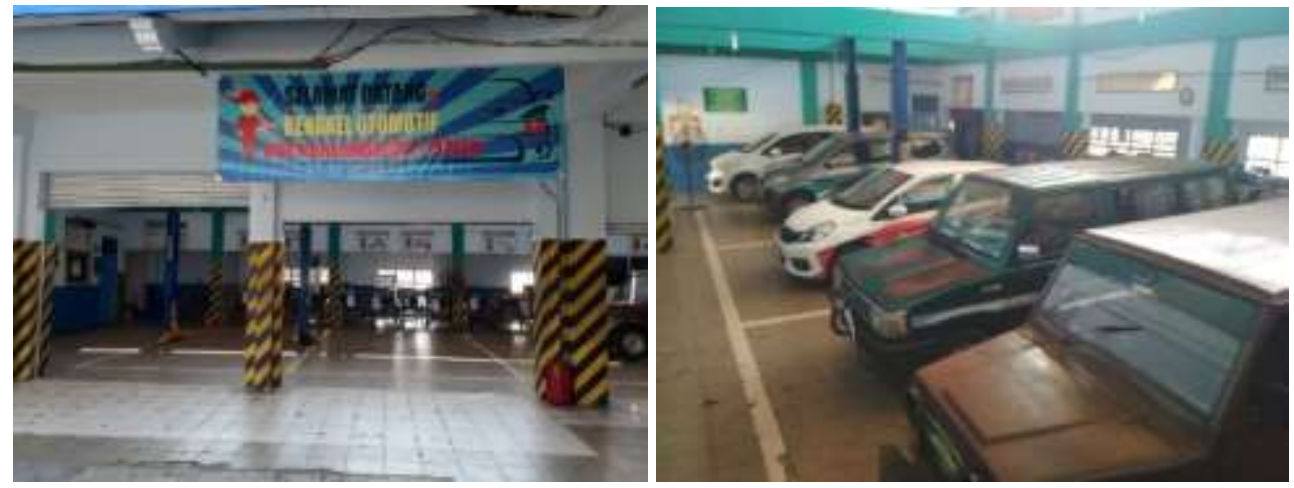

Figure 1. Automotive Engine Workshop Room

The next practice workshop is the Automotive Chassis Workshop, and the area is used to practice the chassis system on light vehicles. The chassis workshop room has a side section layout used as a storage area for practical media, and the middle area serves as a chassis practice location. There is a Tire Changer engine and Wheel Balancing machine that is kept next to a wall pole, and then there are practical media storage racks such as transmission units, propeller units, clutch units, differential units. The area of Automotive Chassis Workshop is $72 \mathrm{~m} 2$, here is a picture of the Automotive Chassis Workshop. 

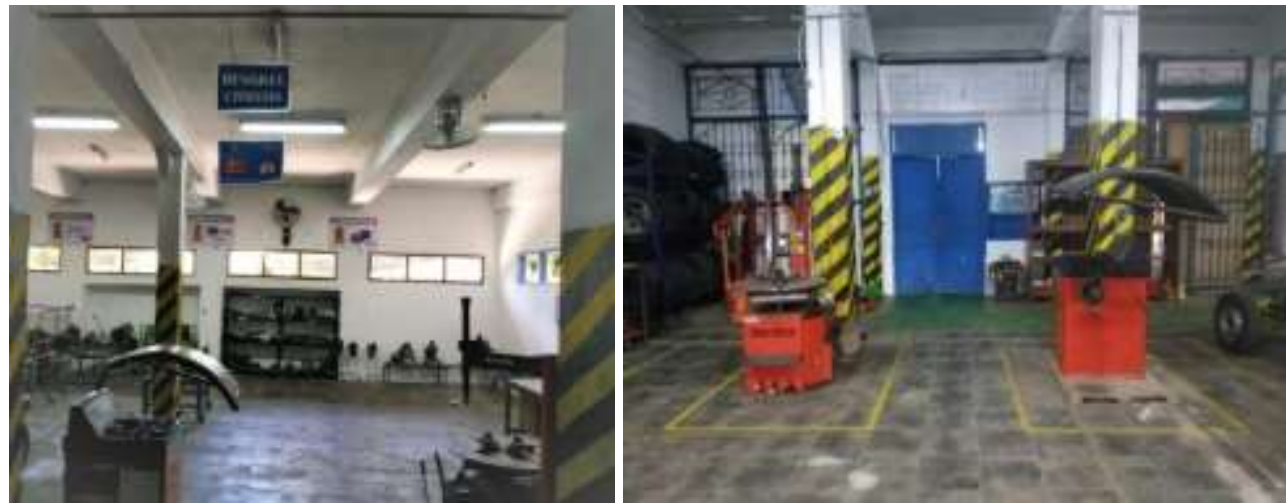

Figure 2. Automotive Chassis Workshop Area

The next practice area is the Automotive Electrical Workshop, which has a room with an area of $24 \mathrm{~m} 2$. The workshop room has a layout, on the side used as a place for storing automotive electronic learning media, and there is a teacher's desk as a place to sit and give material to students before practice begins.
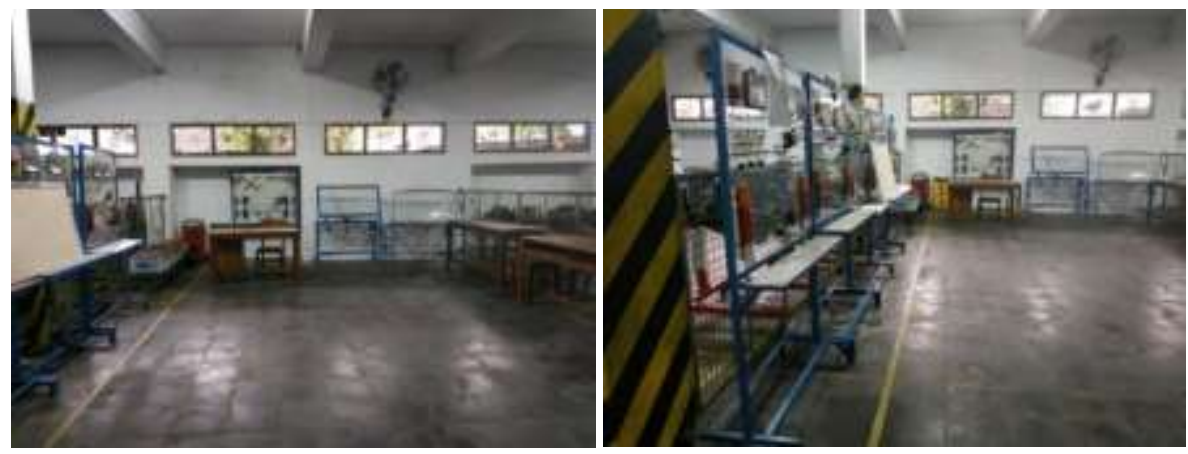

Figure 3. Automotive Electrical Workshop Room

Amenities another in the workshop majors engineering Light Vehicle Engineering is there space specifically for laboratory assistant as a place to provide services to students who do practice in the area of Repair Engineering vehicle of Light. Space special laboratory assistant that, in addition to functioning as a place of service, also serves as a place to store tools specifically and spare parts that will be used by the students to do the practice.
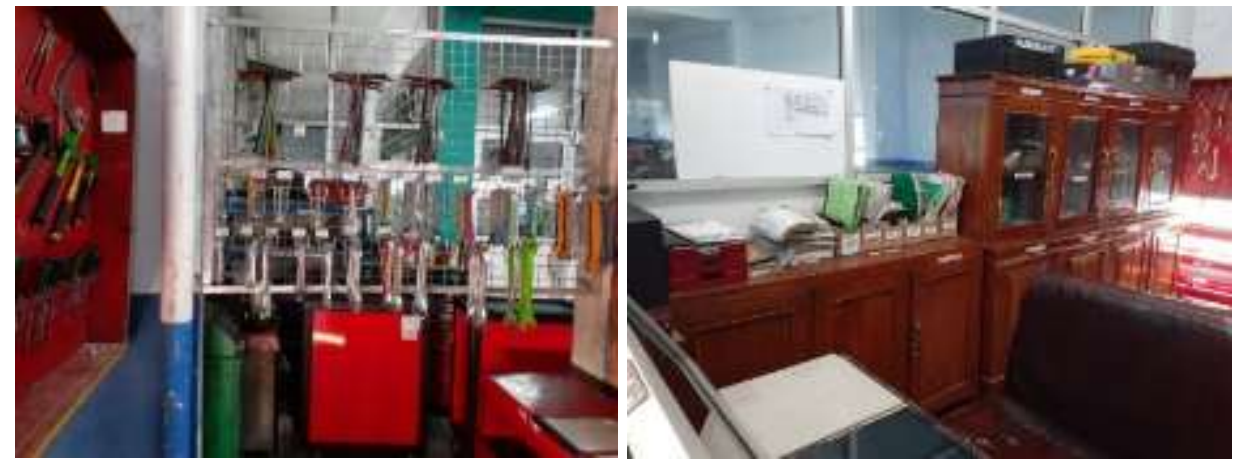

Figure 4. Laboratory assistant room

The next supporting facility is the teacher/instructor room located in the area of Light Vehicle Engineering practice areas where the Head of Workshop and Light Vehicle Engineering Teachers have offices and manage the running of Light Vehicle Engineering practice workshops. The teacher's room has a TV screen facility as a meeting facility, and 
there are a computer and printer unit as an office facility for working on documents contained in the Light Vehicle Engineering major.

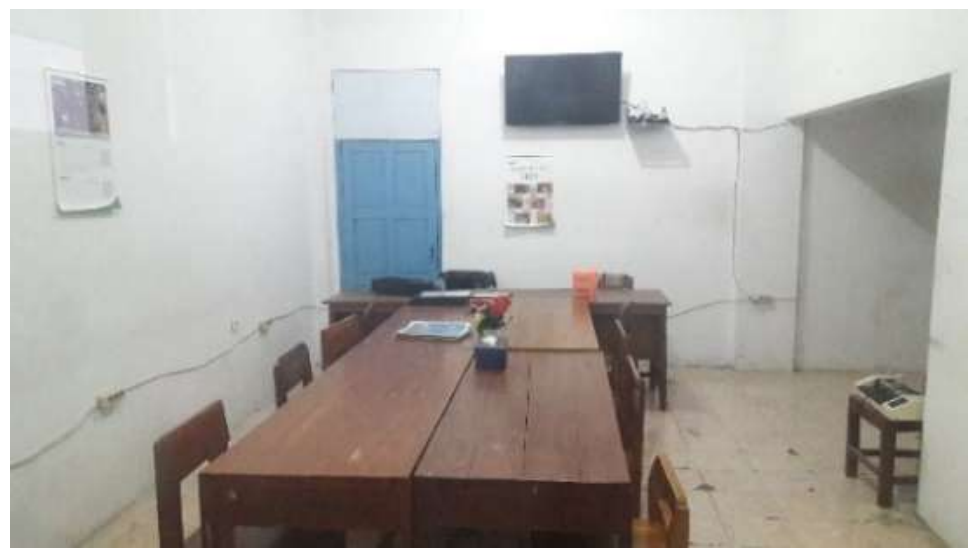

Figure 5. Light Vehicle Engineering Teacher's Room

Almost all eyes subject the practice of using workshop Mechanical Light Vehicle Engineering. Researchers interviewed three subjects, which are taught the eyes of subjects and use the workshop practices of Mechanical Light Vehicle Engineering. Namely, teachers teach eyes lessons Maintenance of Motor Light Vehicle Engineering who use the workshop Engine Automotive further said by the subject 1, the eyes of subjects Maintenance Chassis and Shifters Electric Light Vehicle Engineering who use the workshop Chassis Automotive further said by the subject 2, and the eyes of subjects Maintenance Electrical Light Vehicle Engineering who use the workshop practice of Electronics Automotive further said the subject 3.

Based on aspects of light vehicle engineering practice workshop facilities at Muhammadiyah 1 Playen Vocational High School, subject one about engine workshop said as follows: (1) facilities and infrastructure facilities in my opinion when I teach at the engine shop the teaching and learning activities so far have been running quite effectively although many are need to be evaluated. The area of work used is still far from the expected standard when compared with the number of students available and with the use of solid study hours, (2) service in the engine shop is quite good, shown from the performance of the laboratory assistant or toolman who serves students with good practice, (3) the use of media, in my opinion learning media in the engine shop of the feasibility level of the practice media is indeed feasible for elementary and middle classes because what is needed for basic lessons is already fulfilling, but for advanced classes such as class XII the practice media technology used is still too long and not up to date. When viewed in terms of adequacy, the engine practice media have not been sufficiently adequate in terms of the number of practical students compared to the number of media used, (4) suggestions for engine workshops, automotive Workshops due to inadequate student numbers and area areas and inadequate practice media to date.

Based on the aspects of the Light Vehicle Engineering practice workshop facilities at Muhammadiyah 1 Playen Vocational High School, subject two about the chassis workshop stated as follows: (1) the area of the chassis workshop is less balanced when compared to the number of students practicing. So that some practical groups must take the practice media outside the chassis workshop location. Learning that has taken place can be said to be less effective if viewed from the area, the adequacy of the media, the adequacy of the tools, and the feasibility of the media. For example, when evaluating performance, it will take more time, (2) service when the chassis practice is good enough if viewed from the aspect of borrowing tools, but only constrained by the limitations of the adequacy of the 
tools, (3) if viewed from the adequacy of media practice media practices chassis number is not balanced with the number of students practiced. If it is estimated that eight students only use one medium, so it is less than optimal. Judging from the feasibility of chassis practice media, if it is analyzed based on standards, it cannot meet the proper standard because many components cannot be used or are lost. (4) Suggestions for chassis workshops need to recharge the chassis practice media so that it can adjust the number of students practiced and the need for an increase in the area of practicum that is in accordance with the standards.

Based on the aspects of the Light Vehicle Engineering practice workshop facilities at Muhammadiyah 1 Playen Vocational High School, subject three on the electrical workshop said as follows: (1) the automotive electrical workshop area was not yet adequate, because with the current size students lacked sufficient practice space. With a small area of practice when practicing together with other classes with the same practice job, the media and practice tools used are considered to be insufficient. That is because the existence of equipment tools that are not feasible and limited stands, (2) in terms of service in the electronics workshop is considered good. However, because of the limitations of the media and practical tools, students are not optimally carrying out practices in electronic workshops, (3) the existing electricity stands are considered to be insufficient when compared to the number of students, for example, there are currently four lighting stands but can be used for practice only two pieces, Then for the Central Door Lock stand also can not be used for practice so that in the learning process experiencing obstacles, for the AC system stand only has one piece, there are only 1 charging stand and become one with the engine so if there is a concurrent practice the ignition media will take turns leading to ineffective learning. In terms of the feasibility of the electricity practice media, several electrical stands that are no longer suitable for use, such as the Central Door Lock Stand and the lighting stand. That is because there are components that have been damaged/worn and there are no spare parts if they are to be repaired, (4) suggestions for electronic workshops so that the practice learning process in the workshop can run smoothly by increasing the area of practice, holding additional media practices and also practical tools, so students will be more leverage and comfortable while carrying out practice in an electronic workshop.

The next subject is subject 4, namely the Head of the Light Vehicle Engineering Workshop. In connection with the facility which is contained in the workshop Mechanical Light Vehicle Engineering in Muhammadiyah 1 Playen Vocational High School, subject 4 has a view that is not much different from the subject of research beforehand, namely the spacious area, completeness media practice, eligibility media practices, and more highlight to undertake the planning of revamping the building workshops are gradually referring to the building industry or workshop that is standardized. Subject 5 is the head of the program of study, in line with the head of the workshop that is more highlights to perform planning revamping building workshops in order to more efficiently and effectively perform activities of the practice.

In general, workshop work practices Muhammadiyah 1 Playen Vocational High School Department of Mechanical Light Vehicle Engineering already has facility practices are sufficient to support learning. Would but some subjects complained about the broad area of practice in some workshops are still lacking adequate that need their standardization adequacy broad area of workshop practice in accordance with the group learned that doing activities practice in the garage that. To meet the adequacy spacious area needs to be seen on the needs of departments related facilities and infrastructure Workshop in compare with a standard workshop which is ideal, as the standard minimum of amenities practice in the Regulation of the Minister of Education and Culture No. 34 the Year 2018 concerning the type, rate, and a description of the standard infrastructure of space practice. The following is a description of the Minister of Education and Culture Regulation.

Volume 3, Number 1, May 2020 
Table 2. Types, Ratios, and Descriptions of Standard Infrastructure Practical Space Competencies Light Vehicle Engineering Expertise

\begin{tabular}{|c|c|c|c|}
\hline No. & Jenis & Ratio & Deskripsi \\
\hline 1. & Automotive engine work area & $3 \mathrm{~m}^{2} /$ students & Capacity for 9 students \\
\hline 2. & $\begin{array}{l}\text { The work area of the automotive } \\
\text { chassis, spooring and balancing }\end{array}$ & $3 \mathrm{~m}^{2} /$ students & Capacity for 9 students \\
\hline 3. & Automotive electrical work area & $3 \mathrm{~m}^{2} /$ students & Capacity for 9 students \\
\hline 4. & AC system work area & $3 \mathrm{~m}^{2} /$ students & Capacity for 9 students \\
\hline 5. & Instructor sub room and save room & $3 \mathrm{~m}^{2} /$ instructor & Capacity for 9 instructor \\
\hline
\end{tabular}

Workshop practice in Muhammadiyah 1 Playen Vocational High School Department of Mechanical Light Vehicle Engineering has three-rooms workshop practices that workshop Engine Automotive with a broad area of $84 \mathrm{~m} 2$, workshop Chassis Automotive with a broad area of $72 \mathrm{~m} 2$, and the workshop Electrical Automotive with a broad area of $24 \mathrm{~m} 2$ with one room toolman and space teacher. If compared with the reference standard of a minimum of Regulation of the Minister of Education and Culture No. 34 the Year 2018 the vast area of the lab are less meet, because of extensive minimum area of each workshop in the regulation of the broad area only used for capacity 9 students, i.e., with size $3 \mathrm{~m}^{2}$ / participant students, compared with the broad areas on workshop practice in Muhammadiyah 1 Playen Vocational High School with a group studying each class the number average of 33 students. Some inputs regarding the broad area of workshop and equipment media instructional practices that are used in doing teaching practice need to be developed further to support the activities of learning taught in the workshop in order to run with effective, highly needed, soon be realized.

Discussion of the second is about the use of media learning that there are in the garage working practices majors light vehicle engineering. To determine the use of media instructional practices that required the data, the number of students who perform activities of practice every week. Muhammadiyah 1 Playen Vocational High School Department of Mechanical Light Vehicle Engineering has three levels, namely the class X, XI, XII which each level that has three group study, would but that would be described in the study is only 2 level or class alone, which is a class XI and XII because the class X is still studying the material basis and has not been used for three workshops. Following are the data of students majoring in Light Vehicle Engineering at Muhammadiyah 1 Playen Vocational High School:

Table 3. Data on the Number of Students in the Department of Light Vehicle Engineering at Muhammadiyah 1 Playen Vocational High School

\begin{tabular}{cccc}
\hline No. & $\begin{array}{c}\text { Level / } \\
\text { Class }\end{array}$ & $\begin{array}{c}\text { Study } \\
\text { Group }\end{array}$ & $\begin{array}{c}\text { Total } \\
\text { Students }\end{array}$ \\
\hline \multirow{2}{*}{1} & \multirow{3}{*}{ Class XI } & XI OA & 30 \\
& & XI OB & 33 \\
& & XI OC & 29 \\
2 & \multirow{2}{*}{ Class XII } & XII OA & 33 \\
& & XII OB & 34 \\
& & XII OC & 35 \\
\hline
\end{tabular}

In the table, the data are elaborated on group learning students to two levels, namely the class XI and class XII, which each have a number average of 33 students in each class.

Data next is the facility practices that are at the workshop department of Engineering Light Vehicle Engineering Muhammadiyah 1 Playen Vocational High School. The data first is media instructional practices that are in the workshop Mechanical Light Vehicle Engineering Muhammadiyah 1 Playen Vocational High School on Workshop Engine Automotive, described in the table as follows. 
Table 4. Data Learning Media Practice Workshop Engine Department Automotive Engineering Muhammadiyah 1 Playen Vocational High School

\begin{tabular}{|c|c|c|c|c|c|c|c|}
\hline No & Learning Media & Specification & Amount & Unit & Good & $\begin{array}{l}\text { Condition } \\
\text { Medium }\end{array}$ & Broken \\
\hline 1 & Car 1 & Kijang $5 \mathrm{~K}$ & 1 & Unit & 1 & 0 & 0 \\
\hline 2 & Car 2 & Kijang $3 \mathrm{~K}$ & 1 & Unit & 0 & 1 & 0 \\
\hline 3 & Car 3 & Xenia 2008 & 1 & Unit & 1 & 0 & 0 \\
\hline 4 & Car 4 & Colt T & 1 & Unit & 0 & 0 & 1 \\
\hline 5 & Car 5/ Car trainer & Hijet 1000 & 1 & Unit & 0 & 0 & 1 \\
\hline 6 & EFI Engine Stand & Honda & 1 & Unit & 0 & 0 & 1 \\
\hline 7 & EFI Engine Stand & Kijang 7K & 1 & Unit & 1 & 0 & 0 \\
\hline 8 & EFI Engine Stand & T. Corolla & 1 & Unit & 0 & 0 & 1 \\
\hline 9 & EFI Engine Stand & T. Avanza & 2 & Unit & 0 & 0 & 2 \\
\hline 10 & EFI Engine Stand & T. Inova & 1 & Unit & 0 & 1 & 0 \\
\hline 11 & $\begin{array}{l}\text { Gasoline Engine } \\
\text { Stand }\end{array}$ & T. Kijang 3K & 3 & Unit & 3 & 0 & 0 \\
\hline 12 & $\begin{array}{l}\text { Gasoline Engine } \\
\text { Stand }\end{array}$ & T. Kijang 4K & 1 & Unit & 1 & 0 & 0 \\
\hline 13 & $\begin{array}{l}\text { Gasoline Engine } \\
\text { Stand }\end{array}$ & T. Kijang 5K & 5 & Unit & 3 & 0 & 2 \\
\hline 14 & $\begin{array}{l}\text { Gasoline Engine } \\
\text { Stand }\end{array}$ & Suzuki Carry & 1 & Unit & 0 & 1 & 0 \\
\hline 15 & $\begin{array}{l}\text { Gasoline Engine } \\
\text { Stand }\end{array}$ & D Zebra & 1 & Unit & 0 & 1 & 0 \\
\hline 16 & Diesel Engine Stand & M. L300 & 3 & Unit & 1 & 0 & 2 \\
\hline 22 & Cylinder Head & - & 5 & Unit & 0 & 5 & 0 \\
\hline 23 & Toyota Corona car & Toyota & 1 & Unit & 0 & 0 & 1 \\
\hline \multirow[t]{2}{*}{24} & Engine Overhaul & General & 5 & Unit & 3 & 2 & 0 \\
\hline & & Amount & & & 14 & 11 & 11 \\
\hline
\end{tabular}

On the table are elaborated on media instructional practices Workshop Engine Automotive. From these data, it can be seen that the learning media with conditions that are still good with the amount 14 , moderate conditions with the number 11 , while the condition is damaged or cannot be used at all with the amount 11 .

Data next is the medium of learning practices Workshop Chassis Automotive. Data are in explained in Table as follows.

Table 5. Data Learning Media Practical Workshop Chasis Department of Automotive Engineering Muhammadiyah 1 Playen Vocational High School

\begin{tabular}{|c|c|c|c|c|c|c|c|}
\hline No & Learning Media & Specification & Amount & Unit & Good & $\begin{array}{l}\text { Condition } \\
\text { Medium }\end{array}$ & Broken \\
\hline 1 & Wheel balance & Chang young & 1 & Unit & 1 & 0 & 0 \\
\hline 2 & Tire Changer & Genius & 1 & Unit & 1 & 0 & 0 \\
\hline 3 & Zebra transmission & - & 3 & Unit & 2 & 1 & 0 \\
\hline 4 & $\begin{array}{l}\text { NISSAN Automatic } \\
\text { Transmission }\end{array}$ & - & 1 & Unit & 1 & 0 & 0 \\
\hline 5 & $\begin{array}{l}\text { Suzuki Carry } \\
\text { transmission }\end{array}$ & - & 8 & Unit & 6 & 2 & 0 \\
\hline 6 & Kijang transmission & - & 4 & Unit & 3 & 0 & 1 \\
\hline 7 & Clutch Stand & - & 1 & Unit & 0 & 0 & 1 \\
\hline 8 & $\begin{array}{l}\text { Front Transmission } \\
\text { Stand }\end{array}$ & - & 1 & Unit & 0 & 0 & 1 \\
\hline 9 & Differential/ Gardan & - & 3 & Unit & 2 & 1 & 0 \\
\hline 10 & Tire Rack & - & 1 & Unit & 1 & 0 & 0 \\
\hline 11 & Brake drum & - & 4 & Unit & 4 & 0 & 0 \\
\hline 12 & Propeller Shaft & - & 8 & Unit & 4 & 4 & 0 \\
\hline 13 & Steering System & - & 5 & Unit & 0 & 3 & 2 \\
\hline 14 & Wheel Axle & - & 2 & Unit & 2 & 0 & 0 \\
\hline 17 & $\begin{array}{l}\text { Manual Transmission } \\
\text { Stand }\end{array}$ & - & 1 & Unit & 0 & 1 & 0 \\
\hline 18 & $\begin{array}{l}\text { Automatic } \\
\text { Transmission Stand }\end{array}$ & - & 1 & Unit & 1 & 0 & 0 \\
\hline 19 & Disc Brake Stand & Amount & 1 & Unit & $\begin{array}{c}0 \\
28\end{array}$ & $\begin{array}{c}0 \\
12\end{array}$ & $\begin{array}{l}1 \\
6 \\
\end{array}$ \\
\hline
\end{tabular}

Volume 3, Number 1, May 2020 
Data which describe in a table that states that the number of media instructional practices are still in the condition of both is 28 , then the media learning that the conditions were with amount 12 , while media practices that are already not able to be used at once with the amount 6.

The next data is the learning media for Automotive Electrical Workshop practices. Data are in explained in the table as follows:

Table 6. Data Learning Media Practical Workshop Automotive Electrical Engineering Department of Automotive Engineering Muhammadiyah 1 Playen Vocational High School

\begin{tabular}{|c|c|c|c|c|c|c|c|}
\hline No & Learning Media & Specification & Amount & Unit & Good & $\begin{array}{l}\text { Condition } \\
\text { Medium }\end{array}$ & Broken \\
\hline 1 & Electrical Trainer & - & 6 & Unit & 3 & 2 & 1 \\
\hline 2 & $\begin{array}{l}\text { Conventional Ignition Engine } \\
\text { Stand }\end{array}$ & - & 8 & Unit & 5 & 1 & 2 \\
\hline 3 & $\begin{array}{l}\text { Electronic Ignition Engine Stand } \\
\text { (CDI) }\end{array}$ & - & 2 & Unit & 1 & 1 & 0 \\
\hline 4 & Alternator & - & 8 & Unit & 6 & 2 & 0 \\
\hline 5 & Regulator & - & 8 & Unit & 5 & 3 & 0 \\
\hline 6 & AC Trainer & - & 2 & Unit & 1 & 0 & 1 \\
\hline 7 & Motor Stater & - & 8 & Unit & 5 & 3 & 0 \\
\hline 8 & EFI Engine Stand & - & 4 & Unit & 2 & 1 & 1 \\
\hline 9 & GDI Unit engine stand & - & 2 & Unit & 0 & 0 & 2 \\
\hline 10 & Audio Trainer & - & 1 & Unit & 0 & 0 & 1 \\
\hline 11 & Battery & GS Astra & 11 & Unit & 3 & 3 & 5 \\
\hline 12 & $\begin{array}{l}\text { Trainer Alarm, Central Lock dan } \\
\text { Power Window }\end{array}$ & $=0$ & 1 & Unit & 0 & 0 & 1 \\
\hline \multicolumn{5}{|c|}{ Amount } & 31 & 16 & 14 \\
\hline
\end{tabular}

The table are described data on media instructional practices Workshop Electrical Automotive. Data that can be seen that the media learning with the condition are still good with the amount 31 , media learning with the condition of being amount 16 , while the condition of damaged or not be used at all with the amount 14 .

To review the use of practical learning media, it is necessary to use equipment data, which is the schedule of each class in the Department of Light Vehicle Engineering Muhammadiyah 1 Playen Vocational High School doing practical activities. The following is a schedule of practices at the Light Vehicle Engineering workshop:

Table 7. Schedule Practice the workshop Mechanical Light Vehicle Engineering Muhammadiyah 1 Playen Vocational High School

\begin{tabular}{ccccccc}
\hline NO & CLASS & MONDAY & TUESDAY & WEDNESDAY & THURSDAY & FRIDAY \\
\hline 1 & XIOA & PKKR & PMKR & & & PSPTKR \\
2 & XIOB & & PKKR & PMKR & PSPTKR & \\
3 & XIOC & PSPTKR & & & PKKR & PMKR \\
4 & XIIOA & PMKR & PKKR & PSPTKR & & \\
5 & XIIOB & & PSPTKR & PKKR & PMKR & \\
6 & XIIOC & PSPTKR & & & PKKR & PMKR \\
\hline
\end{tabular}

Based on of table schedule practices that can we see in one day there are eye subjects equal though different classes, such as the example day Monday there were eyes lessons PSPTKR in class XI OC and XII OC, meaning that in one day there are two classes that use one garage the same the number of students 29 for class XI and 35 for class XII, while vast areas and equipment practices of the workshop is very limited. Later in the day Tuesday there are two eyes of subjects are equal again that PKKR which means in the first workshop there are two classes are similar to the eyes of subjects are the same, in addition to extensive 
areas that are less fulfilling, facilities media practice was also going to feel very less, plus more on day of the same are the eyes of subjects PMKR, which according to the interviews of the subject three that support the eyes of subjects PKKR mention that one of the job practice there that use an engine stand from workshop engines on the day it is also used to practice PMKR.

From the description of the data contained in the discussion of the third, the complaint of a subject interview about the lack of area of practice in various workshops that are in the Department of Engineering Light Vehicle Engineering and lack of media practices resulting from: (1) a comparison group learned that doing the practice with a broad area of workshop practice is not balanced, (2) the schedule of eyes lessons are the same in one day which resulted in the participant students do practice in simultaneously in a single time in the workshop are spacious area is very less fulfilling and of course, the media practice also will increasingly do not meet as used by 2 class, (3) a lack of facilities the practice resulted in learning to walk less effective, as should each borrow media and means of one with the other, even a garage with workshop to another.

The results of the study are in line with Kurniawan (2017), the adequacy of facilities and infrastructure of the automotive workshop of Muhammadiyah 1 Playen Vocational High School to meet industrial competence in the category of " Not Fulfilling. " Exposure results of research that the same happened at Piri Sleman Vocational High School are made by (Setianto \& Sulistyo, 2018), level feasibility of infrastructure practice competency expertise Motorcycle Engineering at Piri Sleman Vocational High School in the category has not been feasible with the level of achievement of $50 \%$. Then more distant again, subjects 1, 2, 3 much hope that the broad area of the garage and completeness of the media by revamping workshop practice Mechanical Light Vehicle Engineering for immediately in realization.

\section{CONCLUSION}

The conclusions of the research this is a facility practice in workshop Mechanical Light Vehicle Engineering Muhammadiyah 1 Playen Vocational High School until the moment it is still quite capable of supporting the activities of learning to teach will but less effective. Workshop practice in Muhammadiyah 1 Playen Vocational High School Department of Mechanical Light Vehicle Engineering has a three-roomm workshop practices that workshop Engine Automotive with a broad area of $84 \mathrm{~m} 2$, workshop Chassis Automotive with a broad area of $72 \mathrm{~m} 2$, and the workshop Electrical Automotive with a broad area of $24 \mathrm{~m} 2$ with one room toolman and space teacher. If compared with the reference standard of a minimum of Regulation of the Minister of Education and Culture No. 34 the Year 2018 the vast area of the lab are less meet, because of extensive minimum area of each workshop in the regulation that, wide-area only used for capacity 9 students i.e. with size $3 \mathrm{~m}^{2}$ / students, compared with the broad areas on workshop practice in Muhammadiyah 1 Playen Vocational High School with a group studying each class the number average of 33 students. Less effective instructional practice in the garage caused because: (1) a comparison group learned that doing the practice with a broad area of workshop practice is not balanced, (2) the schedule of eyes lessons are the same in one day which resulted in the participant students do practice in simultaneously in a single time in one workshop that vast area is very less fulfilling and of course the media practice also will increasingly do not meet as used by 2 class, (3) a lack of facilities the practice resulted in learning to walk less effective, as should each borrow media and tools one with another, even one workshop with another workshop.

\section{ACKNOWLEDGEMENT}

The author would like to thank Dr. Budi Santosa that during these already provide guidance and coaching are very valuable. Thank you to the lecturer of Vocational Education in Automotive Technology, Ahmad Dahlan University, who has assisted in exchanging to 
complete this research. Thanks to the teachers of Muhammadiyah 1 Playen Vocational High School, who have helped provide data information so that this research can be completed.

\section{REFERENCES}

Aurigemma, J., Chandrasekharan, S., Newstetter, W., Nersessian, N. J. (2013). Turning experiments into objects: the cognitive processes involved in the design of a lab-ona-chip device. Journal of Engineering Education, 102(1), 117-140.

Brown, R. D. 1979. Industrial Education Facilities. Boston: Allyn and Bacon, Inc.

Dharma, S., Sugiyono, Mulyatiningsih, E., Sutopo., Irwanto., Palunsu, J. E., Triatmojo, P., \& Siswanto, R. (2013). Tantangan Guru SMK Abad 21. Jakarta: Direktorat Pembinaan Pendidik dan Tenaga Kependidikan Menengah.

Kurniawan, A. (2017). Relevansi Sarana dan Prasarana Bengkel Otomotif SMK Muhammadiyah 1 Playen dengan Kompetensi yang Dibutuhkan Industri. Thesis. Yogyakarta: Universitas Negeri Yogyakarta.

MOEC. (2018). Peraturan Menteri Pendidikan dan Kebudayaan Nomor 34 Tahun 2018 tentang Standar Nasional Pendidikan Sekolah Sarana dan Prasarana untuk Sekolah Menengah Kejuruan/Madrasah Aliyah Kejuruan. Jakarta: Ministry of Education and Research.

MONE. (2003). Undang-Undang RI Nomor 20 Tahun 2003 Tentang Sistem Pendidikan Nasional. Jakarta: Ministry of National Education.

Nurdin, \& Hartati, S. (2019). Metodologi Penelitian Sosial. Surabaya: Media Sahabat Cendekia.

Rochadi, L. H. (2011).Pengelolaan workshop praktek jurusan bangunan di SMK yang efektif dan efisien menuju standar bengkel di industri. Makalah disajikan dalam Workshop Pengelolaan Bengkel SMKJawaTengah Tahun 2011. Semarang.

Salindeho, T. L. (2010). Pengembangan laboratorium sebagai upaya untuk meningkatkan kualitas mahasiswa jurusan PKK. Prosiding dalam Seminar Internasional Peran LPTK Dalam Pengembangan Pendidikan Vokasi di Indonesia (pp. 521-526). Denpasar: Universitas Pendidikan Ganesha.

Setianto, Z, \& Sulistyo, B. (2018). Kelayakan Sarana dan Prasarana Praktik Program Studi Keahlian Teknik Sepeda Motor di SMK Piri Sleman. E-Jurnal Pendidikan Teknik Otomotif, 24(2).

Sudira, P. (2012). Filosofi dan Teori Pendidikan Vokasi dan Kejuruan. Yogyakarta: UNY Press.

Sukardi, T. (2008). Pengembangan Model Bengkel Kerja Praktik SMK. Dissertation. Yogyakarta: Universitas Negeri Yogyakarta.

Sukardi, T. (2016). Pengaruh Kelayakan Bengkel Pemesinan dan Prestasi Belajar Pemesinan Frais terhadap Kesiapan Kerja sebagai Juru Frais. Jurnal Pendidikan Vokasional Teknik Mesin, 4(8), 569-576.

Thier, H. D. (1970). Teaching elementary school science. a laboratory approach. New York: Heath and Company. 
